\title{
Impact of Seaweed Extract as A Partial Replacement of Mineral N Fertilizers on Fruiting of Taimour Mango Trees
}

\author{
F. F. Ahmed", A. M. K. Abdelaal ${ }^{*}$ and M. M. Refaai** \\ *Horticulture Department, Faculty of Agriculture, Minia \\ University, Minia and ${ }^{* *}$ Central Lab of Organic Agriculture, \\ Agricultural Research Centre, Cairo, Egypt,
}

\begin{abstract}
7 HIS STUDY was carried out during 2013 and 2014 seasons to examine the effect of foliar application of seaweed extract four times at 1 to $8 \%$ as an alternative to mineral $\mathrm{N}$ fertilizers on growth, plant pigments, nutrients, namely $\mathrm{N}, \mathrm{P}, \mathrm{K}, \mathrm{Mg}, \mathrm{Zn}, \mathrm{Fe}, \mathrm{Mn}$ and $\mathrm{Cu}$ in the leaves, yield and fruit quality of 'Taimour' mango trees. mineral $\mathrm{N}$ $(1000 \mathrm{~g} \mathrm{~N} /$ tree / year) was added at percentages 0.0 to $100 \%$ as inorganic source in the form of amonnium nitrate

Using the 50 to $75 \%$ mineral $\mathrm{N}$ source plus 1 to $2 \%$ seaweed extract gave good results on all the studied parameters comparing with using $\mathrm{N}$ as $100 \%$ mineral as well as when inorganic $\mathrm{N}$ was added at 0.0 or $25 \%$ ?. Applying only inorganic was superior than not applying mineral $\mathrm{N}$ even when foliar application of seaweed extract at $8 \%$ was applied. The increasing content of the investigated parameters was significantly related to the reduction of mineral $\mathrm{N}$ percentage from 100 to $0.0 \%$ and at the same time to increasing concentrations of seaweed extract from 0.0 to $8 \%$. The results obtained in the present study indicates that four application of seaweed extract at $2 \%$ to Taimour mango trees, plus reduction of inorganic $\mathrm{N}$ fertilizers by $50 \%$ gave the best results regarding yield and fruit quality
\end{abstract}

Keywords: Mango, Yield, Fruit quality, Nutrition,

Poor yield in mango cv. Taimour grown under Minia Region conditions is considered as a major problem that faces mango growers in such area. Unbalanced malnutrition as well as unsuitable environmental conditions are considered the main causes for decline on the yield. Most studies carried out recently emphasized the beneficial effects of controlling $\mathrm{N}$ uptake as well as application of seaweed extract on checking this serious problem. For avoiding the use of chemicals, application of natural products was arisen. (Cabrera et al., 2003). Application of seaweed extract as an organic biostimulant is quickly becoming an accepted practice in fruit orchards. It has been used as a soil conditioner and slow release fertilizer for over a century. It derives from Ascophyllum nedosum algae and has many important regularly roles in plants such as controlling different disorders as well as improving growth and fruiting due to its higher content of $\mathrm{N}, \mathrm{P}, \mathrm{K}, \mathrm{Mg}$, vitamins $\mathrm{B}_{1}, \mathrm{~B}_{2}, \mathrm{~B}_{6}$ and cytokinins (Fornes et al., 2002, Khanszada et al., 2007 and Khan et al., 2009). 
The studies carried out by Mouftah (2007), Mohamed et al. (2008), Mahmoud (2012) and Abdelaal et al. (2012) emphasized the beneficial effects of applying different sources of $\mathrm{N}$ on fruit crops rather than using ammonium nitrate alone.

Spraying seaweed extract to different fruit crops has been. found to improve yield and fruit quality by many researchers Gobara (2004), Hegab and Shaarawy (2005), Ebeid - Sanaa (2007), Ahmed et al. (2008), Abd El-Motty- Elhamet al. (2010), ElSayed- Esraa (2010), Mohamed and El- Sherawy (2013) and Gamal (2013).

The target of this study was examining the effect of partially replacing mineral $\mathrm{N}$ by spraying seaweed extract on yield of Taimour mango trees.

\section{Material and Methods}

This study was conducted during 2013 and 2014 seasons on 15 uniform in vigour 12-years old Taimour mango trees grafted onto polyembryonic mango seedling rootstocks in a private orchard located at Minia district, Minia Governorate, Upper Egypt. The texture of the soil was clay. The analys is of the soil where the trees are planted was carried out according to the procedures outlined by Wilde et al. (1985) and indicates a clay texture (Table 1)

TABLE 1. Analysis of the soil

\begin{tabular}{|l|c|}
\hline Constituent & Values \\
\hline Sand \% & 4.2 \\
\hline Silt \% & 12.0 \\
\hline Clay \% & 83.8 \\
\hline Texture & Clay \\
\hline O.M. $\%$ & 2.1 \\
\hline pH $(1: 2.5$ extract) & 7.63 \\
\hline $\mathrm{EC}\left(1: 2.5\right.$ extract) $\mathrm{mmhos} / 1 \mathrm{~cm} 25^{\circ} \mathrm{C}$ & 0.81 \\
\hline CaCO $\%$ & 1.52 \\
\hline Total $\%$ N $\%$ & 0.10 \\
\hline Available P (olson method, $\mathrm{ppm})$ & 5.2 \\
\hline Available K (ammonium acetate, $\mathrm{ppm})$ & 420 \\
\hline
\end{tabular}

The trees are planted at $7 \times 7$ meters apart with water provided through surface irrigation. The trees were subjected to the standard horticultural practices for mango cultivation except those dealing with the application of $\mathrm{N}$ at different sources as well as seaweed extract.

This study included the following five treatments:

- Application of the $\mathrm{N}(1000 \mathrm{~g} \mathrm{~N} /$ tree / year) via 100\% inorganic N (2985.1 g ammonium nitrate / tree / year).

- Application of the $\mathrm{N}$ via $75 \%$ inorganic (2238.8 g ammonium nitrate / tree / year) + spraying seaweed extract at $1 \%$

- Application of the $\mathrm{N}$ via $50 \%$ inorganic (1492.5 g ammonium nitrate / tree / year) + spraying seaweed extract at $2 \%$

Egypt. J. Hort. Vol. 42, No. 1 (2015) 
- Application of the $\mathrm{N}$ via $25 \%$ inorganic (746.3 $\mathrm{g}$ ammonium nitrate / tree / year) + spraying seaweed extract at $4 \%$

- Application of the $\mathrm{N}$ via $0.0 \%$ inorganic $\mathrm{N}+$ spraying seaweed extract at $8 \%$

Each treatment was replicated three times, one tree for each. Ammonium nitrate fertilizer $(33.5 \% \mathrm{~N})$ as a source of mineral $\mathrm{N}$ was divided into three equal batches applied at March, April and May during both seasons. Seaweed extract (Table 2) was sprayed four times at the last week of Feb. and at 21 days intervals. Triton B as a wetting agent was added at $0.05 \%$ to all seaweed extract solutions and spraying was done till runoff. Randomized complete block design was followed.

TABLE 2. Chemical analysis of seaweed extract (Algae 600 seaweed)

\begin{tabular}{|l|c|}
\hline Constituents & Values \\
\hline Organic matter \% & 45 \\
\hline Total N \% & 0.6 \\
\hline $\mathrm{P} \%$ & 6 \\
\hline $\mathrm{K} \%$ & 20 \\
\hline Amino acids & 4 \\
\hline $\mathrm{Mg}$ & 0.06 \\
\hline $\mathrm{Ca}$ & 1.0 \\
\hline $\mathrm{Fe}$ & 0.3 \\
\hline $\mathrm{S} \%$ & 1.0 \\
\hline $\mathrm{Cu}(\mathrm{ppm})$ & 30 \\
\hline Appearance & Brownish powder \\
\hline
\end{tabular}

Twenty leaves from Spring growing cycle were chosen on the medium of four labeled branches (four shoots for each direction) for measuring the leaf area according to Ahmed and Morsy (1999). In these fresh leaves, chlorophylls a \& b and total chlorophylls (mg / 100 g F.W.) were recorded according to the technique by Von-Wettstein (1957). Following the procedure recommended by Summer (1985) twenty six months mature leaves from non-fruiting shoots in the Spring growth cycle (were taken $\left(1^{\text {st }}\right.$ week of Sept.) for determination of N, P, K, $\mathrm{Mg}$ and $\mathrm{Ca}$ (as \%) and $\mathrm{Zn}, \mathrm{Fe}, \mathrm{Mn}$ and $\mathrm{Cu}$ ( as ppm), Fruit retention \%, number of fruits / tree, yield per tree (kg.), fruit weight (g.), T.S.S. \%, total acidity (as citric acid/ $100 \mathrm{ml}$ juice), total and reducing sugars \%, crude fibre \% was also determined following the official methods of analysis (A.O.A., 2000) .Nitrate and nitrite concentrations were also measured ( $\mathrm{ppm}$ ) in the fruit juice following the procedures set by Ridnour- Lisa, et al. (2000).

Statistical analysis was done according to Mead et al., (1993) and treatments were compared using new L.S.D. at $5 \%$. 


\section{Results and Discussion}

Effect of using seaweed extract as a partial replacement of inorganic $N$ fertilizer on leafarea.

Data in Table 3 clearly show that supplying the trees with $\mathrm{N}$ as 50 to $75 \%$ inorganic plus spraying the trees four times with seaweed extract at $2 \%$ significantly stimulated the leaf area relative to using inorganic $\mathrm{N}$ at percentages lower than $50 \%$ over with the application of seaweed extract at $4 \%$ to $8 \%$ or when inorganic $\mathrm{N}$ was added at $100 \%$ of the inorganic $\mathrm{N}$. Using $\mathrm{N}$ as $100 \%$ inorganic significantly was followed by enhancing the leaf area rather than using $\mathrm{N}$ as 0.0 to $25 \%$ inorganic plus spraying seaweed extract at 4 to $8 \%$. The maximum leaf area was recorded on the trees that received $\mathrm{N}$ as $50 \%$ inorganic $\mathrm{N}$ plus carrying out four sprays of seaweed extract at $2 \%$. The trees sprayed with seaweed extract four times at $4 \%$ without inorganic $\mathrm{N}$ fertilization gave the minimum values. These results were true during both seasons.

Effect of using seaweed extract as a partial replacement of inorganic $N$ fertilizer on leaf chemical composition.

Data in Tables 3 \& 4 clearly show that plant pigments namely chlorophylls a $\& \mathrm{~b}$, total chlorophylls and mineral elements like $\mathrm{N}, \mathrm{P}, \mathrm{K}, \mathrm{Mg}, \mathrm{Ca}, \mathrm{Zn}, \mathrm{Fe}, \mathrm{Mn}$ and $\mathrm{Cu}$ in the leaves were significantly improved in response to fertilizing the trees with $\mathrm{N}$ as 0.0 to $75 \%$ inorganic plus spraying the trees four times with seaweed extract at 1 to $8 \%$ relative to using $\mathrm{N}$ via inorganic $\mathrm{N}$ alone. The increases in concentrations of these parameters were significantly associated with reducing inorganic $\mathrm{N}$ percentages from 100 to $0.0 \%$ and at the same time increasing percentages of seaweed extract from 0.0 to $8 \%$. The maximum values were recorded on the trees that received four sprays of seaweed extract at $8 \%$ only. The trees received $\mathrm{N}$ as $100 \%$ inorganic $\mathrm{N}$ gave the lowest values. These results were true during both seasons.

Effect of using seaweed extract as a partial replacement of inorganic $N$ fertilizer on fruit retention and yield.

It is clear from the data in Table that using $\mathrm{N}$ as 50 to $75 \%$ in organic as well as spraying seaweed extract at 1 to $2 \%$ significantly improved fruit retention as well as yield expressed in number of fruits / tree and weight $(\mathrm{kg}$.) relative to the application of $\mathrm{N}$ as $100 \%$ inorganic or when $\mathrm{N}$ was added as 0.0 to $25 \%$ inorganic $\mathrm{N}$ even with the application of seaweed extract at 4 to $8 \%$. A significant decline on the fruit retention $\%$ and yield was observed when inorganic $\mathrm{N}$ percentage was lowered to 0.0 to $25 \%$ inorganic under the application of seaweed extract at 4 to $8 \%$. Using $\mathrm{N}$ as $100 \%$ inorganic was significantly superior than using it as 0.0 to $25 \%$ inorganic even with the application of seaweed extract at 4 to $8 \%$. The best results with regard to yield were obtained with using $\mathrm{N}$ as $50 \%$ inorganic + spraying seaweed extract four times at $2 \%$. Under such promised treatment, yield per tree reached 38.6 and $39.6 \mathrm{~kg}$ compared with the yield of the trees received $\mathrm{N}$ as $100 \%$ inorganic that reached 27.5 and $28.2 \mathrm{~kg}$ during both seasons, respectively. The percentage of increase in yield due to using the previous treatment over the check treatment reached 40.4 during both seasons.

Egypt. J. Hort. Vol. 42, No. 1 (2015) 
TABLE 3. Effect of replacing partially mineral $\mathbf{N}$ fertilization by using seaweed extract on the leaf area, plant pigments as well as percentages of $N, P, K$ and $\mathrm{Mg}$ in the leaves of Taimour mango trees during 2013and 2014 seasons.

\begin{tabular}{|c|c|c|c|c|c|c|c|c|}
\hline \multirow[t]{2}{*}{ Treatment } & \multicolumn{2}{|c|}{$\underset{(\mathrm{cm})^{2}}{\text { Leaf area }}$} & \multicolumn{2}{|c|}{$\begin{array}{c}\text { chlorophyll a } \\
\text { (mg/100 g } \\
\text { F.W.) }\end{array}$} & \multicolumn{2}{|c|}{$\begin{array}{c}\text { Chlorophyll b } \\
\text { (Mg/100 g } \\
\text { F.W.) }\end{array}$} & \multicolumn{2}{|c|}{$\begin{array}{c}\text { Total } \\
\text { chlorophylls } \\
\text { (Mg/100 g } \\
\text { F.W.) }\end{array}$} \\
\hline & 2013 & 2014 & 2013 & 2014 & 2013 & 2014 & 2013 & 2014 \\
\hline $\mathrm{N}$ as $100 \%$ M.N. & 80.0 & 81.2 & 8.1 & 8.3 & 3.3 & 3.4 & 11.4 & 11.7 \\
\hline $\begin{array}{l}\mathrm{N} \text { as } 75 \% \mathrm{MN}+1 \\
\% \text { seaweed }\end{array}$ & 84.0 & 85.7 & 8.7 & 9.0 & 3.5 & 3.7 & 12.2 & 12.7 \\
\hline $\begin{array}{l}\mathrm{N} \text { as } 50 \% \mathrm{MN}+2 \\
\% \text { seaweed }\end{array}$ & 87.0 & 88.9 & 9.5 & 10.0 & 4.0 & 4.0 & 13.5 & 14.0 \\
\hline $\begin{array}{l}\mathrm{N} \text { as } 25 \% \mathrm{MN}+4 \\
\% \text { seaweed }\end{array}$ & 77.6 & 78.0 & 10.0 & 11.2 & 4.3 & 4.4 & 14.3 & 15.6 \\
\hline $\begin{array}{l}\mathrm{N} \text { as } 0.0 \% \mathrm{MN}+8 \\
\% \text { seaweed }\end{array}$ & 75.3 & 76.0 & 11.9 & 11.9 & 4.6 & 4.7 & 16.5 & 16.6 \\
\hline New L.S.D. at $5 \%$ & 1.0 & 1.0 & 0.3 & 0.3 & 0.2 & 0.2 & 0.4 & 0.4 \\
\hline \multirow{2}{*}{ Treatment } & \multicolumn{2}{|c|}{ Leaf $N \%$} & \multicolumn{2}{|c|}{ Leaf $P \%$} & \multicolumn{2}{|c|}{ Leaf $\mathrm{K} \%$} & \multicolumn{2}{|c|}{ Leaf Mg \% } \\
\hline & 2013 & 2014 & 2013 & 2014 & 2013 & 2014 & 2013 & 2014 \\
\hline $\mathrm{N}$ as $100 \%$ M.N. & 1.61 & 1.64 & 0.18 & 0.17 & 1.33 & 1.32 & 0.51 & 0.52 \\
\hline $\begin{array}{l}\mathrm{N} \text { as } 75 \% \mathrm{MN}+1 \\
\% \text { seaweed }\end{array}$ & 1.71 & 1.76 & 0.22 & 0.21 & 1.40 & 1.40 & 0.55 & 0.56 \\
\hline $\begin{array}{l}\mathrm{N} \text { as } 50 \% \mathrm{MN}+2 \\
\% \text { seaweed }\end{array}$ & 1.80 & 1.86 & 0.26 & 0.25 & 1.47 & 1.46 & 0.60 & 0.61 \\
\hline $\begin{array}{l}\mathrm{N} \text { as } 25 \% \mathrm{MN}+4 \\
\% \text { seaweed }\end{array}$ & 1.88 & 1.92 & 0.30 & 0.29 & 1.55 & 1.52 & 0.65 & 0.66 \\
\hline $\begin{array}{l}\mathrm{N} \text { as } 0.0 \% \mathrm{MN}+8 \\
\% \text { seaweed }\end{array}$ & 1.95 & 2.01 & 0.35 & 0.33 & 1.62 & 1.63 & 0.71 & 0.71 \\
\hline New L.S.D. at $5 \%$ & 0.06 & 0.07 & 0.03 & 0.03 & 0.05 & 0.04 & 0.03 & 0.03 \\
\hline
\end{tabular}

M.N. = Mineral N 
TABLE 4. Effect of replacing partially mineral $\mathbf{N}$ fertilization by using seaweed extract on the leaf content of $\mathrm{Ca}($ as \%), $\mathrm{Zn}$, Fe and $\mathrm{Mn}$ and $\mathrm{Cu}$ (as ppm) , fruit retention (as \%) and yield per tree of Taimour mango trees during 2013and 2014 seasons.

\begin{tabular}{|c|c|c|c|c|c|c|c|c|}
\hline \multirow[t]{2}{*}{ Treatment } & \multicolumn{2}{|c|}{ Leaf Ca \% } & \multicolumn{2}{|c|}{ Leaf Zn (ppm) } & \multicolumn{2}{|c|}{ Leaf Fe (ppm) } & \multicolumn{2}{|c|}{$\begin{array}{ll}\begin{array}{l}\text { Leaf } \\
(\mathrm{ppm})\end{array} & \text { Mn }\end{array}$} \\
\hline & 2013 & 2014 & 2013 & 2014 & 2013 & 2014 & 2013 & 2014 \\
\hline $\mathrm{N}$ as $100 \%$ M.N. & 2.33 & 2.22 & 49.5 & 50.0 & 52.5 & 53.0 & 52.9 & 54.0 \\
\hline $\begin{array}{l}\mathrm{N} \text { as } 75 \% \mathrm{MN}+1 \\
\% \text { seaweed }\end{array}$ & 2.41 & 2.50 & 54.0 & 55.0 & 55.5 & 56.0 & 55.0 & 57.0 \\
\hline $\begin{array}{l}\mathrm{N} \text { as } 50 \% \mathrm{MN}+2 \\
\% \text { seaweed }\end{array}$ & 2.51 & 2.61 & 58.0 & 59.0 & 59.0 & 60.0 & 58.0 & 60.0 \\
\hline $\begin{array}{l}\mathrm{N} \text { as } 25 \% \mathrm{MN}+4 \\
\% \text { seaweed }\end{array}$ & 2.64 & 2.74 & 62.3 & 64.0 & 62.0 & 64.0 & 61.0 & 62.5 \\
\hline $\begin{array}{l}\mathrm{N} \text { as } 0.0 \% \mathrm{MN}+8 \\
\% \text { seaweed }\end{array}$ & 2.81 & 2.91 & 66.0 & 67.3 & 65.6 & 67.0 & 64.3 & 65.0 \\
\hline New L.S.D. at 5\% & 0.07 & 0.07 & 2.5 & 2.3 & 2.2 & 2.1 & 1.9 & 2.0 \\
\hline \multirow{2}{*}{ Treatment } & \multicolumn{2}{|c|}{ Leaf Cu (ppm) } & \multicolumn{2}{|c|}{ Fruit retention \% } & \multicolumn{2}{|c|}{ No. of fruits / tree } & \multicolumn{2}{|c|}{ Yield/tree (kg.) } \\
\hline & 2013 & 2014 & 2013 & 2014 & 2013 & 2014 & 2013 & 2014 \\
\hline $\mathrm{N}$ as 1 & 1.22 & 1.17 & 0.76 & 0.75 & 130.0 & 133.0 & 27.5 & 28.2 \\
\hline $\begin{array}{l}\mathrm{N} \text { as } 75 \% \mathrm{MN}+1 \\
\% \text { seaweed }\end{array}$ & 1.26 & 1.22 & 0.84 & 0.86 & 145.0 & 148.0 & 32.9 & 33.7 \\
\hline $\begin{array}{l}\mathrm{N} \text { as } 50 \% \mathrm{MN}+2 \\
\% \text { seaweed }\end{array}$ & 1.31 & 1.27 & 0.94 & 0.97 & 160.0 & 163.0 & 38.6 & 39.6 \\
\hline $\begin{array}{l}\mathrm{N} \text { as } 25 \% \mathrm{MN}+4 \\
\% \text { seaweed }\end{array}$ & 1.36 & 1.33 & 0.71 & 0.69 & 120.0 & 123.0 & 31.4 & 32.5 \\
\hline $\begin{array}{l}\mathrm{N} \text { as } 0.0 \% \mathrm{MN}+8 \\
\% \text { seaweed }\end{array}$ & 1.41 & 1.40 & 0.66 & 0.62 & 110.0 & 112.0 & 30.5 & 31.5 \\
\hline New L.S.D. at 5\% & 0.03 & 0.04 & 0.04 & 0.04 & 8.0 & 7.0 & 0.8 & 0.8 \\
\hline
\end{tabular}

M.N. = Mineral N

Effect of using seaweed extract as a partial replacement of inorganic $N$ fertilizer on fruit quality

Data in Table 5 clearly show that supplying the trees with $\mathrm{N}$ as 0.0 to $75 \%$ inorganic plus seaweed extract at 1 to $8 \%$ significantly improved fruit quality in terms of increasing fruit weight, T.S.S. $\%$, total and reducing sugars $\%$ and decreasing total acidity $\%$, crude fibre $\%$, nitrate and nitrite in the juice relative to using $\mathrm{N}$, completely via inorganic $\mathrm{N}$ alone. The promotion on fruit quality was significantly associated with reducing percentages of inorganic $\mathrm{N}$ from 100 to $0.0 \%$ and at the same time increasing concentrations of seaweed extract from 0.0 to $8 \%$. The best results with regard to fruit quality were observed with using four sprays of seaweed extract at $8 \%$ with the neglection of using inorganic $\mathrm{N}$. Unfavourable effects on fruit quality were observed on the trees that fertilized with $\mathrm{N}$ completely via inorganic $\mathrm{N}$. These results were true during both seasons.

The higher own content of seaweed extract from essential nutrients namely $\mathrm{N}, \mathrm{P}, \mathrm{K}, \mathrm{Mg}, \mathrm{Ca}, \mathrm{Fe}$ and $\mathrm{Cu}$ as well as amino acids (see table 3), as well as vitamins $\mathrm{B}$, antioxidants, organic acids and fats, as well as its benefits as a soil conditions and natural fungicides for controlling different disorders indicated by other researchers , (Ito and Hori, 1989, Fornes et al., 2005 , Khanszada et al., 
2007 and Khan et al., 2009) could explain its positive action on growth and fruiting of Taimour mango trees.

TABLE 5. Effect of replacing partially mineral $N$ fertilization by using seaweed extract on some physical and chemical characteristics of the fruits of Taimour mango trees during 2013and 2014 seasons.

\begin{tabular}{|c|c|c|c|c|c|c|c|c|}
\hline \multirow[t]{2}{*}{ Treatment } & \multicolumn{2}{|c|}{$\begin{array}{c}\text { Fruit weight } \\
\text { (g.) }\end{array}$} & \multicolumn{2}{|c|}{ T.S.S. \% } & \multicolumn{2}{|c|}{$\begin{array}{c}\text { Total acidity } \\
\% \\
\end{array}$} & \multicolumn{2}{|c|}{$\begin{array}{c}\text { Total sugars } \\
\% \\
\end{array}$} \\
\hline & 2013 & 2014 & 2013 & 2014 & 2013 & 2014 & 2013 & 2014 \\
\hline $\mathrm{N}$ as $100 \%$ M.N. & 211.9 & 212.3 & 14.2 & 14.0 & 0.303 & 0.299 & 11.1 & 10.8 \\
\hline $\begin{array}{l}\mathrm{N} \text { as } 75 \% \mathrm{MN}+1 \% \\
\text { seaweed }\end{array}$ & 227.0 & 228.0 & 14.5 & 14.5 & 0.281 & 0.261 & 11.4 & 11.3 \\
\hline $\begin{array}{l}\mathrm{N} \text { as } 50 \% \mathrm{MN}+2 \% \\
\text { seaweed }\end{array}$ & 241.0 & 243.0 & 14.7 & 14.9 & 0.260 & 0.226 & 11.7 & 11.7 \\
\hline $\begin{array}{l}\mathrm{N} \text { as } 25 \% \mathrm{MN}+4 \% \\
\text { seaweed }\end{array}$ & 262.0 & 264.0 & 15.0 & 15.3 & 0.240 & 0.201 & 12.0 & 12.0 \\
\hline $\begin{array}{l}\mathrm{N} \text { as } 0.0 \% \mathrm{MN}+8 \% \\
\text { seaweed }\end{array}$ & 277.0 & 281.0 & 15.3 & 15.7 & 0.201 & 0.183 & 12.3 & 12.3 \\
\hline New L.S.D. at $5 \%$ & 11.0 & 11.2 & 0.2 & 0.2 & 0.020 & 0.022 & 0.2 & 0.2 \\
\hline \multirow{2}{*}{ Treatment } & \multicolumn{2}{|c|}{$\begin{array}{l}\text { Reducing } \\
\text { Sugars \% }\end{array}$} & \multicolumn{2}{|c|}{$\begin{array}{c}\text { Crude fibre } \\
\%\end{array}$} & \multicolumn{2}{|c|}{ Nitrite (ppm) } & \multicolumn{2}{|c|}{$\begin{array}{c}\text { Nitrate } \\
\text { (ppm) }\end{array}$} \\
\hline & 2013 & 2014 & 2013 & 2014 & 2013 & 2014 & 2013 & 2014 \\
\hline $\mathrm{N}$ as $100 \%$ M.N. & 3.1 & 3.0 & 1.00 & 0.92 & 3.00 & 3.00 & 7.11 & 6.97 \\
\hline $\begin{array}{l}\mathrm{N} \text { as } 75 \% \mathrm{MN}+1 \% \\
\text { seaweed }\end{array}$ & 3.3 & 3.3 & 0.84 & 0.80 & 2.11 & 2.11 & 5.00 & 4.97 \\
\hline $\begin{array}{l}\mathrm{N} \text { as } 50 \% \mathrm{MN}+2 \% \\
\text { seaweed }\end{array}$ & 3.6 & 3.6 & 0.71 & 0.66 & 1.92 & 1.88 & 4.11 & 3.91 \\
\hline $\begin{array}{l}\mathrm{N} \text { as } 25 \% \mathrm{MN}+4 \% \\
\text { seaweed }\end{array}$ & 4.0 & 3.9 & 0.60 & 0.50 & 1.41 & 1.31 & 3.19 & 3.00 \\
\hline $\begin{array}{l}\mathrm{N} \text { as } 0.0 \% \mathrm{MN}+8 \% \\
\text { seaweed }\end{array}$ & 4.2 & 4.3 & 0.41 & 0.32 & 1.00 & 0.97 & 2.00 & 1.99 \\
\hline New L.S.D. at $5 \%$ & 0.2 & 0.2 & 0.09 & 0.10 & 0.04 & 0.03 & 0.04 & 0.04 \\
\hline
\end{tabular}

M.N. = Mineral N

These results are in harmony with those obtained by Gobara (2004), Hegab and Sharawy (2005), Ebeid- Sanaa (2007), Ahmed et al. (2008), El- SayedEsraa (2010) and Gama (2013). The results of Mouftah (2007), Mohamed et al. (2008), Mahmoud (2012) and Abdelaal et al. (2012) emphasized the possibility of using seaweed extract as a partial replacement of inorganic $\mathrm{N}$ fertilizer. 


\section{Conclusion}

Under the condition of this experiment it was found that in order to improve yield and quality of Taimour mango trees it is suggested to fertilize the trees with $\mathrm{N}$ (1000 g / tree / year) via 50\% inorganic plus spraying the trees four times with seaweed extract at $2 \%$.

\section{References}

Abdelaal, A.M.K., Ahmed, FF., and Mahmoud, Kh. M.H. (2012) Partial replacement of chemical $\mathrm{N}$ fertilizers in Balady mandarin orchard through application of extracts of yeast, seaweed and farmy ard manure. Minia J. of Agric. Res. \& Develop., 32 (1), $129-145$.

Abd El-Motty Elham, Z., Shahin, M.F.M., El-Shiekh, M.H. and Abd El-Migeed, M.M.M. (2010) Effect of Algae extract and yeast application on growth nutritional status, yield and fruit quality of Keitte mango trees. Agric. Bio. J. Am., 3, 421-429.

Ahmed, F.F. and Morsy, M.H. (1999) A new method for measuring leaf area in different fruit species. Minia. J. Agric. Res. \& Dev., 19, 97-105.

Ahmed, F.F., Gobara, A.A., Abo El- Komsan, E.E. and Gamal, A.F. (2008) Growth and fruiting of Washington Navel orange trees as affected by some antioxidant and algae extract treatments. Inter. Conf. for Envrion. Studies Menufia Univ. pp. 200- 220.

A.O.A.C. (2000) "Official Methods of Analysis", $16^{\text {th }}$ ed. A.O.A.C. Benjamin Franklin Station, Washington, D.C., U.S.A., pp. 490-510.

Cabrera, O., Valera-Garza, J. and Aguiree Medina, J.F. (2003) Use of biofertilizers in agricultural crops on the central region of Mexico. Agricultural Technica en Mexico Instituttro Nacinal de

Ebeid- Sanaa, M. (2007) The promotive of seaweed extract and boron on growth and fruiting of Hindy Bisinnara mango trees. Minia J. Agric. Rev. \& Develop., 27 (3) 579594.

El- Sayed- Esraa, M.H. (2010) Behaviour of Ewaise mango trees to foliar application of some nutrients and seaweed extract. Ph. D. Thesis, Fac. of Agric., Minia Univ., Egy pt.

Fornes, F., Sanches- Perales, M. and Guardiola, J.L. (2002) Effect of seaweed extract on the productivity of ade Nules clementine mandarin and Navlina orange. Botanica Marina, 45(5), 487-489.

Gamal, A.F.O. (2013) Fruiting of Washington Navel orange trees in relation to application of Seaweed extract, boron and citric acid. Ph.D Thesis, Fac. Agric., Minia Univ., Egypt.

Gobara, A.A. (2004) Effect of Algae extract and yeast on fruiting of Zaghloul date palms. J. of Agric. Sci. Mansoura Univ., 29 (1), 5209-5220. 
Hegab, M.M.Y. and Shaarawy, A.M.A. (2005) Effect of Alage extract and mono potassium phosphate on growth and fruiting of Balady orange trees. Minia J. Agric. Res. \& Develop., 25 (1), 50-72

Ito, K. and Hori, K. (1989) Seaweed chemical composition and potential food uses. Food Rev. Int., 5, 101- 144.

Khan, W., Rayirth, P., Sowmyalakshmi, S.S., Munday, A., Prasan, Th. R. Mark, H., Alam, T. and Balakrisham, P. (2009) seaweed extracts as biostimulants of plant growth and development plant growth Regue, J. Plant Growth Regul., 28, 386-399

Khanszada, A.K., Shaikh, W., Kazi, W., Kabir, S. and Soofa, S. (2007) Antifungal activity, elemental analysis and determination of total proteins of seaweed. Pak J. Bot., 39, 931- 937.

Mahmoud, Kh, M.H. (2012) Reducing inorganic N fertilizer in Balady mandarin orchard through application of extracts of yeast, seaweed extract and farmy ard manure. M.Sc. Thesis, Fac. Agric., Minia Univ., Egypt.

Mead, R., Currow, R.N. and Harted, A.M. (1993) "Statistical Methods in Agricultural and Experimental Biology", ${ }^{\text {nd }}$ ed., Chapman \& Hall London. pp 10- 44.

Mohamed, A.Y. and El-Sherawy, O.A.M. (2013) Effect of seaweed extract on fruiting of Hindy Bisinnara mango trees. J. Amer. Sc., 9 (6), 537-544.

Mohamed, M.A. Gobara, A.A., Ragab, M.A. and Mouftah, R.T. (2008) Response of Taimour and Zebda mango trees to application of organic and biofertilizaiton along with seaweed extract. $1^{\text {st }}$ Inter. Conf. for Environ. Studies Menufia Univ. pp. 250-280.

Mouftah, R.T. (2007) Physiological studies on biofertilization of mango trees cvs Taimour and Zebda. Ph.D. Thesis, Fac. Agric., Minia Univ., Egypt.

Ridnour, Lisa, A., Sim-Julia, E., Michael, A.H., David, A.W., S can, M.M., Garry, R.P. and Douglas, R.S. (2000) A spectrophotometric method for the direct and quantitation of Nitric oxide, nitrite and nitrate in cell culture Media. Analytical Biochemistry, 281, 273-229.

Summer, M.E. (1985) Diagnosis and Recommendation Integrated System (DRIS) as a Guide to Orchard Fertilization. Hort. Abst., 55 (8),1-21

Von-Wettstein, D.V. (1957) Chlorophyll- Lthale under submikrosphpische formiuechrel der plastiden celi, Drp. Trop. Res. Amer. Soc. Hort. S., 20 , 427-433.

Wilde, S.A., Corey, R.B., Layer, J.G. and Voigt, G.K. (1985) "Soil and Plant Analysis for Tree Culture", Oxford and IBH publishing Co., New Delhi, India. 


\section{تأثير مستخلص الأعشاب البحرية كبديل جزئس للأسمدة النتروجينية

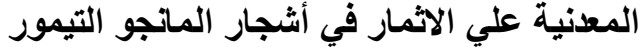

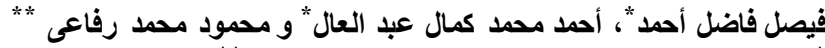

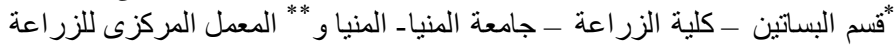

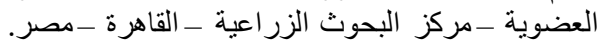

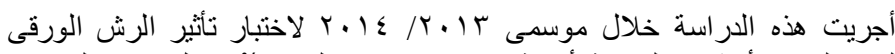

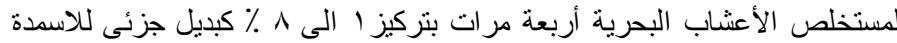

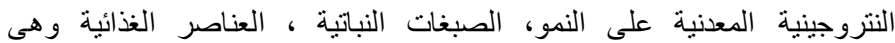

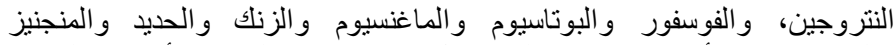

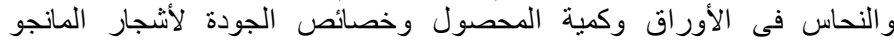

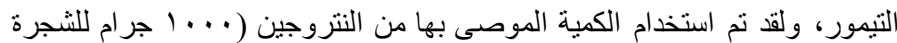

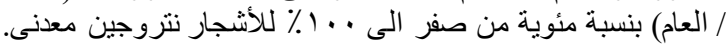

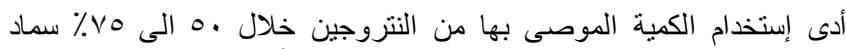

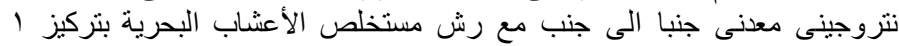

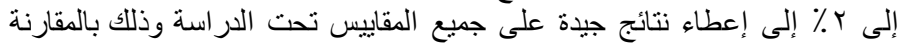

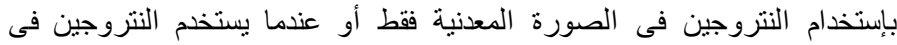

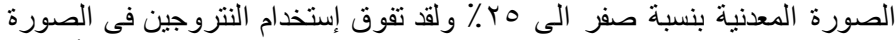

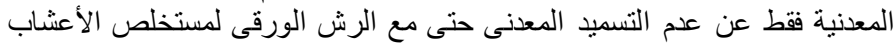

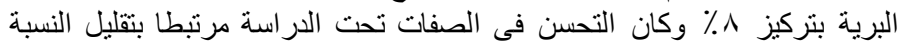

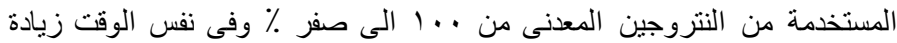

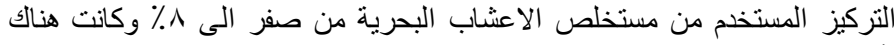

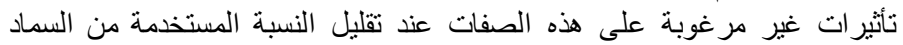

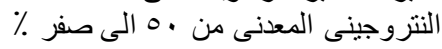

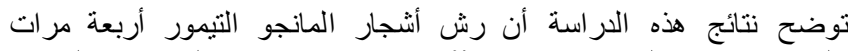

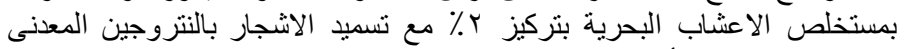

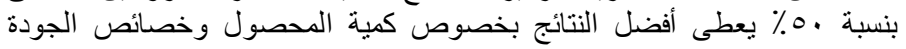

